\title{
The Impact of Foreign Music on the Development of Selected Slovak Popular Music Styles and Genres since 1989
}

\section{Anna Babjaková}

Compared to the former Czechoslovakia, the 1990s saw the beginning of a new era characterised by a socialist country undergoing transformation into a marketbased economy, which was accompanied by changes that had an impact on the popular music scene. As early as the 1950s, the communist regime - marked by state-dominated control over all spheres of the country's economy, including the cultural scene, which was conceived as a basis to support the ruling ideology - enforced the aesthetics of socialist realism, which was intertwined with the country's ideological backdrop. ${ }^{1}$ The success of a work of art in the area of popular music was essentially determined by the producer's compliance with the spirit of the officially accepted doctrine. Music criticism was dominated by negative responses to the Western European development of music as an art and questioning technical innovation and its aesthetic manifestation.

In one of his post-revolutionary studies entitled Státní kulturnípolitika a česká populárni hudba v obdobi tzv. normalizace [The State's Cultural Policy and Czech Popular Music in the Normalisation Period] from 2008, Jan Blüml describes the actions taken by state-controlled art agencies, which were part of the country's totalitarian infrastructure, drawing attention to the censure of popular music, accompanied by official and unofficial orders pertaining to the prohibition of music production and secured requirements applicable to potential artists wanting to register with art agencies. The network of art agencies had a significant impact

\footnotetext{
${ }^{1}$ For further definitions of the starting points for socialist country aestheticians, see S. Kopčákovás study entitled Vývoj hudobno-estetiskébo myslenia na Slovensku [The Development of MusicalAesthetic Thought in Slovakia]. The method of Socialist Realism was declared at the $1^{\text {st }}$ All-Russian Congress of Soviet writers in 1943, focusing on making an impact on the uneducated. It included V. I. Lenin's theory of reflection, which was generally accepted and based on the claim that art is to reflect reality. In the 1930s, K. Marx criticised those who associated creative art with religion, highlighting the cognitive function of art and paying special attention to the aesthetic acquisition of knowledge about the world. Marxist ideologist G. V. Plechanov criticised the impact of the bourgeois system on art, supporting the idea that the development of the fine arts is determined by class struggle. See Kopčáková, p. 148.
} 
on the development and shape of the domestic popular music scene, which Blüml analysed in his study in great detail. The author describes the system of qualification playback sessions (conceived as a significant ideological tool), the phenomenon of general requalification (a gradual transformation of rock music to pop music), and the 20-month procedure which reduced the number of potential artists by half.

\begin{abstract}
Rather than being based solely on a rehearsal, the new model of examinations involved three separate steps: a test focused on music theory based on art school requirements, a rehearsal (musicians had to sing folk songs), and an interview centring on cultural and political issues. Although successful candidates were put into one of three salary categories, this did not mean that the categorisation would also apply in the subsequent requalification procedure - there was always the possibility of "a ban on artistic activity" (which was either general, regional, or medium-specific) - even solely due to inappropriate appearance. Such bans also applied unofficially - the organiser would have been informed in advance who was acceptable and who wasn't. ${ }^{2}$
\end{abstract}

In his analysis of communism-era popular music, Petr Bílek sees what is commonly referred to as "normalisation pop" as a manifestation of discourse communication. ${ }^{3}$ In his opinion, the music dominating this period is just as standardised as any other cultural artefact maximising the commercial potential of its industrial nature. Pop music was created for the purpose of producing easily perceivable images of the world constructed in accordance with the official ideology. The influence of foreign music was so strictly censured that any penetration from abroad was followed by sanctions in the spirit of the strict dogmatic standards of the communist regime, which associated a majority of Western European music styles with a potential ideological enemy of the state. ${ }^{4}$ In his discussion on the availability of foreign music in Koncepce populárni hudby pre česká mediálni studia [Popular Music Conceptions for Czech Media Studies], M. Pospíšil says:

In the 1980s, the standard channels for disseminating parallel information included black-market swap meetings that allowed the participants to exchange

\footnotetext{
2 Jan Blüml, "Státní kulturní politika a česká populární hudba v období tzv. normalizace: k činnosti státních uměleckých agentur v letech 1969-1989," in Promèny hudby v mènícím se svètě, ed. Ivan Poledňák (Olomouc: Palacký University, 2007), 43-56. Quoted from Michal Pospíšil, "Koncepce studia populární hudby pro česká mediální studia” (PhD diss., Charles University in Prague, 2013), 103. 3 Bílek in Pospíšil, "Koncepce studia."

${ }^{4}$ When it comes to specific types of artistic influence, it might be interesting to analyse the great number of songs originally authored by writers and musicians from abroad which were adopted, appropriated in terms of lyrics, and performed by Czechoslovak artists before 1989 as part of domestic music production.
} 
Western European vinyl, as well as posters, books, concert tour lists, or translations of lyrics. In addition to cassette recorder clubs, Vaněk also refers to a relatively new area that is significant to the spread of music - video recorders. The way he sees it, the beginning of the 1980s saw "a great migration of peoples to Western Bohemia with moving into dwellings with properly installed antennas" that made it possible for the viewer to watch the annual television programme called Rockpalast. Antennas were also positioned to receive Formel 1 (an ARD television music chart), Musikladen (ZDF), and especially Bayern 3 (as well as Austrian channels). ${ }^{5}$

The post-1989 period brought fundamental changes reflecting the transformation of the infrastructure associated with popular music production and distribution. This involved the transformation of state-owned record agencies into private record companies and the arrival of foreign record companies onto the market, including Universal Music, Sony Music, BMG, and Warner Music. The era also saw the establishment of private radio and cable stations, which mediated the broadcast of foreign music channels such as MTV, MCM, and VIVA. There were also a few attempts to establish domestic or local music channels, as exemplified by the Košice-based music television Music Box at the beginning of the 1900s, which had a significant impact not only on the transformation of the established reception habits, but also on music production, which was increasingly determined by music from abroad. This was followed by the establishment of the first recording studios, which were capable of producing music in a globalised market and responding to fast-changing trends.

One of the first studios from the1990s with digital recording equipment was Košice-based Savid, which facilitated the production of a great number of recordings, especially during the Euro disco era (recording tracks by MC Erik and Barbara, among others). Another studio was called Phoenix - although it no longer exists, it provided room for producers such as Martin and Marián Kavulič, who currently support the pop singer Kristína - the nominee who represented Slovakia at the 2010 Eurovision Song Contest with her dance hit song entitled "Horehronie" (authored by M. Kavulič and K. Peteraj). Another noteworthy studio is Bratislava-based Creative Music House, which has supported projects by artists such as Misha (representing a wave of $\mathrm{RnB}$ and soul music influence on Slovak popular music), Tina, and Zdenka Predná. The producers M. Graus and M. Kachút (former members of the group called B3) have been making contributions to the country's top-notch mainstream music production for a long time now. Currently, a major part of the mainstream is supported by the Bratislava-based studio Little Beat (the producer duo of Hruška and Šrámek,

${ }^{5}$ Pospíšil, “Koncepce studia,” 94. 
running projects for Celeste Buckingham and Mike Spirit) and Prešov-based Studio 7 (Randy Gnepa).

Another significant type of transformation during this period of time was the fact that recording software became more and more available to the public at large - mostly used by the hip-hop community and electronic music makers, often in home-based studios. Having produced music that made it to the MTV channels, This Is Kevin was generally considered to be the most ground-breaking project in the sphere of electronic music in the 1990s. Nowadays, significant electronic music makers include Pjoni and Ink Midget, Stratasoul, Jimmi Pe and Štefan Královič, the producer behind projects such as The Uniques, Nvmeri and FVLCRVM, whose track remix BankRoll ${ }^{6}$ made it to the $\mathrm{BBC}$ radio broadcast this year.

All of the producers mentioned above are self-taught. Štefan Královič describes his early days of music-making as an era influenced by listening to other musicians, recording songs from the radio, learning to play by ear and, later, developing his skills playing live. He mentions two modes of implementing intuition in his creative process, one of which is experimentation (involving electronic sounds or instruments), the other including previously heard patterns combined with his new coincidence-based musical ideas. ${ }^{7} \mathrm{He}$ claims that unpredictability is a major benefit to the composition process, compared to computer programming.

Regarding the composition process, Štefan prefers starting by setting the beat, which he says already includes notions of what later develops into the melody and character of particular instruments tracks. Once the beat has been set, he continues with harmonic structures, avoiding the creation of particular forms. The musical structure contains certain dynamics, such as choruses or melodies that are easily remembered, but his attention is placed more on repetitive patterns, the character of each sound, underlined by the continuous beat. "I sometimes start with the loop and I try to identify its strength. Sometimes, after a few weeks, I combine the patterns as a puzzle, eventually creating a new track." Writing the lyrics is considered to be the most difficult part of the process and often comes last. Štefan often uses pre-text musical structures (vocals), later filled with meaningful lyric content. He considers the assonance of the words to be a tool. Regarding the form of the track, he mentions the rhythmical breaking point (together with a harmonic background), linked to the lyrics to help him distinguish between different parts of the track. Most of the tracks have English lyrics.

\footnotetext{
${ }^{6}$ Other Slovak artists whose tracks have been broadcasted by the $\mathrm{BBC}$ include the electronic projects B-Complex and Foolk.

${ }^{7}$ Improvisation plays a key role in the creative process. He considers it to be an intimate process that allows him to do much more first without audiences, then in front of them. He claims that his inner state during the creative process depends on the sound as it is heard.
} 
The author of the song "Horehronie" and former producer of dance floor music now is concentrating on the production of pop songs; Martin Kavulič highlights the commercial aspect of electronic music and computer programming and its influence on popular music as a phenomenon linked to the consumer nature of the field. He remembers the negative responses of the Slovak radio authorities refusing to accept the new wave of music: "I remember it as something considered to belong to the guys in garages or campuses, playing with their computers; only later, around the year 2005, it became accepted as an alternative to the former acoustic dominance of the production."

An author of numerous Slovak hits, Kavulič considers the whole process of creating music to be deeply intuitive, and claims he often feels as a medium through which music flows. He prefers lyrics to be written first and highlights the role of strong choruses. He says the content of lyrics defines the character of the song, including its tempo, atmosphere and rhythmical structure.

Predominantly characterised by rhythmogenicity, simplified structure, and repetition, the aesthetics of electronic and dance music (Euro disco music in particular), dominant across the globe in the 1990s, was also popular on the Slovak music scene in the period, giving rise to a number of Euro disco projects (groups such as Extasy, Salco, D Nite, Lobby, or Morhotronic), most significantly materialising in the southern Slovak group called Maduar, which later spawned the duo of MC Erik and Barbara and their hit songs "I Feel Good", "You Can't Stop", or "Do It". In 1997, the duo signed a contract with Polygram and continued to exist until 1998 (creating an album entitled 2010 later in 2010). The music and format of the duo complied with the Euro disco music canon: a mixed-gender, two-member line-up with a rapping $\mathrm{MC}$ and a female vocalist singing melodic, catchy chorus segments. A major breaking point was represented by the use of English lyrics, which was caused by access to global markets. The duo took advantage of this opportunity, launching a few singles in Germany, Belgium, Finland, Switzerland, and, later on in 1997, also in Japan.

Being among the authors who study the processes of cultural transfers, Tony Mitchel claims that the process itself has two phases, namely adoption and adaptation, depending on various local cultural, social, economic, and historical circumstances. ${ }^{8}$ Language typically becomes a tool to ensure that the result is authentic, which was particularly evident in Slovakia when it came to hip-hop music. The Euro disco wave capitalised on the fact that in the 1990s the Slovak audience was infatuated with the flood of foreign music across the Slovak radio

${ }^{8}$ Tony Mitchel, Popular Music and Local Identity (London, New York: Leicester University Press, 1996). Quoted from Pospíšil, “Koncepce studia,” 179. 
stations at the time, and the language used served as a means of getting closer to the highly attractive foreign music.

Partly conceived as a fusion including hip-hop culture (represented by rapping passages), which was given an increasing amount of space by the mainstream radio stations in the 1990s, Euro disco music comes with the declamation art of rapping onto the Slovak music scene, introduced as early as in 1995 (the first albums by hip-hop groups such as Zvuk Ulice or Trosky date back to the year 1997) ${ }^{9}$. It should be noted, however, that hip-hop music was part of an emerging subculture that penetrated the mainstream several years later, practically only after 2004, when Kontrafakt released their first album, which later led to standalone projects by the group's rappers Rytmus and Ego. James Lull describes the appropriation process as being comprised of three parts: identifying a cultural pattern in the original social context, cultural mediation, and merging and integrating the context of the target society. The most significant by all means, the middle phase, is comprised of three elements: transculturation (introducing one culture to another via the mass media), hybridisation (mixing cultures), and indigenisation (the process whereby a culture is gradually naturalised, which creates a new cultural area). Lull's approach lends itself easily to the hip-hop subculture in the context of the penetration of foreign music styles into the domestic music scene. ${ }^{10}$

In the Czech Republic, the topic in question is also discussed by Oravcová, ${ }^{11}$ who references particular studies and focuses on analysing rap music lyrics and the way they shape Czech identity: ${ }^{12}$

According to Barrer, the most crucial part for a rapper is to provide an artistic reflection of their own neighbourhood (or home town) and the way they experience life in it. The purpose is to stir the listener into action, attracting the media and creating a unique identity within the commercial sphere of the Slovak music industry. There are several elements that make it different from the gangsta archetype: an emphasis on the rapper's lyrics and lyrical skills; an expression of Slavic solidarity; and a lifestyle associated with hard drugs essential to the rapper's autobiography, although taking hard drugs is strictly disapproved of. [...] On the other hand, the elements that make Slovak rap music similar to American

\footnotetext{
9 Around the year 1992, the rapper known as Vec established the group called Trosky in cooperation with Midi (early on, it was called CRABB \& SiCKLE SYNDICATE). For a certain period of time, they were part of Zvuk ulice. Later on, under Sony BMG, they released an album called Trosky, which was one of the first official Slovak hip-hop records. They also shot a video clip for the track called "Tozmemi", which was also released on vinyl in 1998). Other Slovak groups include: AMO, Názov stavby, Moja Reč, Bene, Hafner a Beyuz, Modre Hory and others.

${ }^{10}$ Lull in Pospíšil, "Koncepce studia," 179.

11 Anna Oravcová, "Raperky a jejich pozice v rámci české hip hopové subkultury”(PhD Diss., Fakulta humanitních studií in Prague, 2010).

${ }^{12}$ Her findings can be applied on Slovak environment as well.
} 
gangsta rap include the use of marihuana; an image characterised by financial success, attracting women, sexism, machismo, and the objectification of women. ${ }^{13}$

Compared to the style of hip-hop that emerged in the immigrant AfricanAmerican and Porto Rican communities in the streets of the Bronx in the late 1960s and early 1970s, the Slovak version of hip-hop music represents a phenomenon mediated by globalisation - a product in the context of simulacra, as stated by Deleuze, who says that in our times we do not get into contact with originals, but only with "repetitions that are not authentic reproductions, only shifted representations that point towards other repetitions, which are the results of other shifts and transformation." ${ }^{14}$

Another particular phenomenon concerns the frequently negative responses voiced by both recipients and popular musicians with regard to the influx of foreign music and domestic efforts to copy it on various levels. This negative perception of the globalisation of music trends can be exemplified by the penetration of Euro disco music elements into Slovak popular music in the mid1990s, or the impact of R\&B or hip-hop elements on popular music in Slovakia after 2000. The aversion induced by the ostentatious adoption of foreign music elements even led to music parodies. For example, the group called Kopytovci voiced their response to MC Erik and Barbara's hit song "Do It", parodying it by rewriting the original song lyrics as "Dojit" (which means "to milk"), creating a caricature of Slovak rural life in contrast to the club culture that emerged in the metropolitan life of Western Europe and the USA. More recently, a few former members of Kopytovci released a project entitled Novy Model, parodying the boom of hip-hop groups in "Otcova rola" [Father's field], which is modelled on the same principles of parody manifested in "Dojit". The song complies with the formal characteristics of rap music style, copying the strongly rhythmic, declarative nature of the vocal track. On the arrangement level, the artists make use of a hip-hop element that was typical for the period of 2000 to 2005 , namely the use of foreign culture samples, frequently Arabic motifs. However, the actual lyrics are in striking contrast to the musical background. ${ }^{15}$ The same type of response to the globalisation of music can be further exemplified by Horkýže Sliže's song called "RnB Soul". ${ }^{16}$

\footnotetext{
13 Oravcová in Pospíšil, "Koncepce studia," 179.

${ }_{14}$ Wolfgang Welsch, Estetické myslenie (Bratislava: Archa, 1993), 154.

15 The chorus lines are as follows: "Ucti si pluh, ucti si voly, ucti si burgyňu, čo klíči na roli. Ucti si cep, ucti si kosu, ucti si žito a na ňom rannú rosu" [Honour the plough, honour the oxen, honour the mangold growing in the field. Honour the flail, honour the scythe, honour the rye and the morning dew on it.]

${ }^{16}$....as stated by Deleuze, who says that, in our times, we do not get into contact with originals, but only with "repetitions that are not authentic reproductions, only shifted representations that point
} 
The penetration of specific musical elements from one culture into another comes with the need to analyse the multiple layers of musical works of art; study the distinctive elements of such works of arts; and identify those that actually end up penetrating into the target culture, giving rise to new structures. The penetration of specific styles into national music traditions very often involves discussions of the issue of authenticity. In one of her studies, ${ }^{17}$ Maria Elisabeth Reicher analyses various components of a work of art in the context of copyrighting ${ }^{18}$ describing the links between works of art and other objects (distinguishing between realisation-, notation-, and production-related relationships). The way she sees it, the process of creating a work of art consists of identifying the essential attributes of the way a work of art is realised. The author discusses the artistic strategy of "appropriation", which involves reusing material in a new context. In the sphere of music, this phenomenon can be as well exemplified by technique of sampling used in Slovak hip hop. The author also addresses the issue of the narrow-minded view expressed in current legislation, which defines elements of a work of art as layers that can be expressed using notation (namely melody and harmony). According to the author, other aspects are generally ignored, although they contribute to the aesthetic characteristics of a work of art, especially in the sphere of popular music.

One of the components makes up the sound of a work of art, namely instrumentation. When it comes to dance/electronic music, we can identify trends in the use of specific sounds or sound effects from a given period which musicians use to get closer to the works of art established on global markets. This worldwide phenomenon is actually associated with many other phenomena, especially non-musical attributes of popular music, such as the musicians' image, the visual elements used in video clips, etc. This behaviour is frequently motivated by a commercial aspect, which leads to the standardisation of popular music, commercial elements being a major part of the whole process. ${ }^{19}$ When it comes to hip-hop music, there are also certain specific attributes that penetrate into the national music markets, including so-called "dissing" - highlighting the weaknesses of another musician in a song, which is an action that is usually followed by a response. One of the most famous disses in Slovakia is associated with the rapper Rytmus' comments on Ivan Tásler and his criticism of IMT SMILE's guitar

towards other repetitions, which are the results of other shifts and transformation." In Welsch, Estetické myslenie. 155.

17 In Pavel Záhradka, Estetika na přelomu milenia (Olomouc: Barrister and Principal, 2010).

${ }^{18}$ For further information on copyrights, see Václav Kramář, Hudebni dílo a plagiát pobledem muzikologie a autorskébo práva (Olomouc: Palacký University, 2014).

${ }_{19}$ Antonín Matzner, Ivan Poledňák, and Igor Wasserberger (eds.), Encyklopedie jazzu a moderní populárni hudby, věcná část (Praha: Supraphon, 1983). 
"sound". On the level of song lyrics, another specific attribute is the use of slang expressions, which is similar to the original hip-hop tradition.

Rytmus is one of the few hip-hoppers who can also be put in the ethnic minority category, which is something that he often refers to in his lyrics. One of the features that is part of both the original version of hip-hop music and its Slovak version is the principle of "keeping it real", which gives fans the impression that the musician's music overlaps with their life. In his songs, Rytmus frequently makes comments on his own status, his transformation, isolation associated with fame, the criticism of the commercial aspects of his career and other.

The distinctive features of Slovak hip-hop music are primarily the social origin of the musicians that must be mentioned. Compared to gangsta rap, which was largely shaped in the 1980s, Slovak hip-hop music is not really an analogous generic. In principle, the Slovak hip-hop subculture can be defined in the same way as Czech hip-hop:

Czech hip-hop does not represent the alternative to the distribution of drugs. In its world, gangs play no major role, and weapons are not an expression of collective resistance to unfavourable conditions. Instead, it is dominated by individual feelings and attitudes; it is a channel characterised by a specific style of musical expression against the backdrop of a set of cultural, ethnic, and class-related specifics that are different from our environment. [...] the significance of hip-hop as a subculture of black resistance got lost in translation, undergoing transformation as a result of a different set of values. It is safe to say that, in our country, outside its cradle, hip-hop is not "black" - instead, it grows into the local culture and, owing to the fact that makes use of the local language, it turns out to be a global phenomenon. ${ }^{20}$

The globalization process and its manifestations are here to stay. The production of popular songs which are strongly influenced by global market is increasing. Radios playing mostly foreign popular music ${ }^{21}$ content have a deep impact on musicians, who, in order to be played on the radio, often adjust their creativity to world-wide trends.

${ }^{20}$ Marta Kolářová (ed.), Revolta stylem. Hudebni subkultury mládeže v České republice (Prague: SLON, 2011), 239.

${ }^{21}$ This situation has led to legislative requirements whereby at least 20 per cent of all broadcast content must be of Slovak origin, preferably with Slovak language lyrics. 


\title{
The Impact of Foreign Music on the Development of Selected Slovak Popular Music Styles and Genres since 1989
}

\begin{abstract}
This study provides a brief outline of the development of mainstream music and popular music content since the fall of the Iron Curtain in Slovakia, mapping the rise of specific music styles, such as club, hip-hop, and electronic music, and providing a brief description of the infrastructure, including recording studios and currently active music producers. In studying the nature of the creative process, it focuses on selected popular musicians (Štefan Královič and Martin Kavulič) who have been active on the music scene in the recent years. The study deals with the nature of various sources of influence on musicians' decision-making, addressing issues such as the role of their education versus their innate musicality and intuitive sensitivity to current trends, the role of globalisation and the media, and certain specific features related to Slovak artists' mainstream music production.
\end{abstract}

\section{Vliv zahraniční hudby na vývoj vybraných stylů a žánrů slovenské populární hudby po roce 1989}

\section{Abstrakt}

Předložená studie stručně popisuje vývoj hlavního proudu populární hudby na Slovensku po pádu „železné opony“. Sleduje vznik konkrétních hudebních stylů, jakými jsou např́klad taneční hudba, hip-hop či elektronika. Článek stručně popisuje infrastrukturu populární hudby včetně problematiky nahrávacích studií, současných aktivních producentů atp. $V$ rámci studia povahy tvůrčího procesu autorka reflektuje vybrané umělce (Śtefan Královič a Martin Kavulič), kteří na scéně působili v nedávané době. Studie sleduje vlivy, jimž zmínění hudebníci podléhali, dále se zabývá otázkami, jakou roli hrálo jejich vzdělání či vrozená hudebnost a intuice ve věci vnímání současných trendů, do jaké míry hudební scénu ovlivňovaly procesy globalizace, medializace atp.

\section{Keywords}

popular music; mainstream; Slovakia; globalization; hip-hop; electronic music 


\section{Klíčová slova}

populární hudba; hlavní proud; Slovensko; globalizace; hip-hop; elektronická hudba

Anna Babjaková

Institute of Aesthetics and Art Culture

Faculty of Arts, University in Prešov

17. novembra 1

08001 Presov, Slovakia

annx12@yahoo.co.uk 